\title{
Geophysical Prospecting
}

IN prospecting for minerals, oils, water, etc., 1 use can be made of the physical characteristics of the materials near the earth's surface. The methods at present adopted can be divided into four groups. The first group utilises the magnetic susceptibility of the materials, the second their density, the third their elasticity and the fourth group comprises various electric methods. The second group comprises the 'gravimetric' methods and the third the 'seismic'. In some cases two or more methods can be applied to the same area and so unwanted factors can be eliminated. The gravimetric method was made possible in 1888 when Baron von Eötvös published his work on the torsion balance. In 1914 Mintrop demonstrated experimentally the possibilities of the seismic methods. Prof. A. O. Rankine discussed the development of geophysical prospecting in his presidential address last year to Section $\mathrm{A}$ of the British Association at York.

In a paper read to the Institution of Electrical Engineers on April 7, J. M. Bruckshaw gave a detailed account of the electrical methods of surveying. As a rule, the interpretations of the electrical surveys are of a qualitative nature and in this respect they are not so good as the gravitational and seismic methods, which give indications of the depth and size of the material for which search is made.

There is now a tendency to develop more precise electrical methods with the object of placing them on a quantitative basis. The importance of making a preliminary geological survey and determining the resistivity of samples of the rock in the neighbourhood is now recognised. The results found in this way impose limitations on the use of the various methods that can be applied. If a known mass of ore occurs in the region under test, the interpretation of the results is greatly simplified by conducting the electrical survey directly over the known body.
As an example of the utility of geo-electrical prospecting, the case of a survey made by $\mathrm{Mr}$. Broughton Edge in Cyprus was described. Mineralisation was suspected from the indications of old Roman activities in the neighbourhood. This led to the ground being examined by means of four adits and three shafts, but without result. Within three days of starting the electrical surveys, the centre was plainly indicated by the equipotential lines. The interpretation was confirmed by driving two adits and these encountered a large pyritic mass, the upper end of which lay immediately below the centre. Although the surface of the ground was very rough the equipotential curves on the map were smooth.

In survey work, rocks and minerals are divided into two classes, metallic conductors and electrolytic conductors: Practically all minerals showing metallic lustre are in the first class. In nearly all methods of electrical prospecting, an equipotential line method is first employed as this takes very little time and locates the most promising areas. These areas do not necessarily represent mineral deposits, for bands of clay and graphite-impregnated schists, etc., yield the same type of anomaly as an ore body. In some cases, geophysics may differentiate between a mineral deposit and a band of clay, but it is generally the geologist who determines which of the indications are caused by ore.

The depth to which the ground can be examined depends on the kind of method used. In the resistivity methods, the ground examined penetrates to a depth approximately equal to the distance between the electrodes. With great depths the results obtained are difficult to interpret. As a rule, it is not convenient to use currents greater than five amperes. Good results are sometimes obtained by using high-frequency alternating currents.

\section{Obituary}

\section{Prof, Victor Goldschmidt}

CCIENCE has to deplore the loss of another of $\checkmark$ her 'grand old men', Germany one of her most distinguished sons, and the world of culture at large one of the most accomplished, versatile and beneficent of its exponents, in the passing on May 8 of Prof. (Herr Geheimrath) Victor Goldschmidt, honorary professor of mineralogy and crystallography at the University of Heidelberg, at the ripe age of eighty years. His name has long been a household word with the small, but now happily increasing, coterie of workers in crystallography, which he was fond of calling the "Queen of Sciences" ; and he was never tired of expressing his intense delight in the wonderful beauty of crystals. Yet so wide were his interests that in many other subjects he was almost equally distinguished, particularly ethnography, astronomy, physiology, colour in art, and tone and harmony in music. Having inherited great wealth-sadly depleted afterwards by the War-he was able to advance the interests of his subjects to an exceptional degree, and became a 'pious founder' in the truest sense of the term.

Born in Mainz on February 10, 1853, of Jewish stock, in the year 1871 he became a student of the Gewerbakademie of Berlin. Then from 1872 until 1878 he attended the celebrated Bergakademie of Freiberg, and during his last three years there acted as an assistant. In order to acquire further experience, however, he migrated in 1878 to the School of Mineralogy and Crystal- 
lography then growing up in Munich, which later became so famous under the guidance of Prof. von Groth; afterwards, in 1879, he went on to Heidelberg, where he took his degree of doctor of philosophy in 1880 .

Prof. Goldschmidt had the inestimable advantage of the life-long help of a devoted and highly intellectual wife, a first cousin (formerly Fräulein von Portheim), who was both a remarkable linguist and keen appreciator of music and art in all its branches. Their home in Heidelberg, where they lived very simply and unostentatiously, but where they literally lavished hospitality and kindness on their many foreign visitors, was replete with valuable art treasures, such as Italian illuminated manuscripts, very early examples of printing, ancient French objets d'art, gems of every kind and a wonderful collection of crystals.

The laboratory of Prof. Goldschmidt at Heidelberg is a private one, which was provided and maintained at his own expense, but with the full concurrence of the University. He usually had working there, under his direction and that of his assistant Dr. Himmel, in mineralogy and crystallography, some ten to fifteen students, and also another half-dozen of more experience engaged in research, either for their doctorates or in a still more mature class of investigation. To this remarkable institution were attracted students possessing some previous experience from all over the world, including quite a number from England (especially Oxford and Cambridge) who were always warmly welcomed. Eventually in 1916 Prof. and Frau Goldschmidt definitely endowed the laboratory, together with an Institute for Folk-lore, and an ethnographical museum which they had also provided, as the "Josefine und Eduard von Portheim Stiftung für Wissenschaft und Kunst", in honour of their parents, Prof. Goldschmidt's mother and Frau Goldschmidt's father. Provision was also specially made for an English research bursary of about $£ I 50$ per annum, to enable an English student of experience and promise but not too well provided with means to work with Prof. Goldschmidt, and incidentally to further friendship between Germany and England. On the eightieth birthday of Prof. Goldschmidt last February, the laboratory was formally named the Victor Goldschmidt Institut für Krystallforschung.

The published scientific papers of Prof. Goldschmidt form an immense list, numbering about 180 , many of them masterpieces on specific minerals. Besides these papers he produced in the years 1914-26 the "Beiträge zur Krystallographie und Mineralogie", and since 1922 the "Heidelberger Akten der von Portheim Stiftung", and the "Materialen zur Naturphilosophie". Perhaps his most valuable contributions concerned blowpipe methods, which he carried to perfection, for the determination of minerals; crystal measurements by the theodolite method (azimuth and polar distance), using the two-circle goniometer which he perfected; and crystal drawing and calculation from the gnomonic projection, which he considerably elaborated. When we add to these his papers on etch- and solution-figures on crystal faces, his "Index der Krystallformen der Mineralien", his "Krystallographische Winkeltabelle", and last but not least his monumental "Atlas der Krystallformen" (1923) in nine volumes of figures and a like number of volumes of text, which took many years to complete, it will be obvious what a magnificent addition to our knowledge Prof. Goldschmidt has left behind him.

On the occasion of his seventy-fifth birthday Goldschmidt was presented with a "Festschrift", containing thirty-three original papers on mineralogy and crystallography, entirely contributed by his old students and a few personal friends ; they included one from the late Dr. T. V. Barker of Oxford, and another by Dr. Mary Porter of the same University, who had received great kindness from Prof. Goldschmidt and his wife during the period of her work at his Heidelberg laboratory before the foundation of the bursary. It was published by the von Portheim Stiftung, under the editorship of Dr. Himmel, and with a foreword of appreciation of Prof. Goldschmidt's work by Prof. Milch. Prof. Goldschmidt was an honorary member of the Mineralogical Society in Great Britain, and of a dozen other scientific societies outside Germany.

Last December and January, Prof. and Frau Goldschmidt were in England, staying with the former's brother in London, and although when visiting the Master of Pembroke and Mrs. Hutchin. son in Cambridge he appeared to be wonderfully vigorous, yet his relatives were then very anxious about his health. On leaving England they did not return home, but travelled to Salzburg in Austria, and before long it became necessary to remove from the hotel to a sanatorium, where Dr. Goldschmidt rapidly became worse, and where he died, as stated, on May 8. The recent happenings to his many Jewish friends in Germany cannot fail to have distressed him, and to have been a source of unhappiness during his last days. Yet he sought to find solace in planning further researches, and especially in compiling a review of the present position of crystallography, so as to discover the lines along which future research might most advantageously be prosecuted.

Unselfish to the end, Goldschmidt's thoughts were ever with the great institution which he had founded in Heidelberg, and now that he has been taken home and buried in that lovely spot by the banks of the Neckar, on the scene of his great life-work, we can only hope that the Stiftung and its traditions and especially the Victor Goldschmidt Institute for Crystal Research will be cherished as the worthiest memorial possible of this truly great man of science and perfect kindly gentleman. May his spirit inspire those who work there to emulate the master, and thus to produce further contributions of real value to our knowledge of the subject, the study of crystals, that was nearest his heart!
A. E. H. Tutron. 